\title{
The Challenge of Non-Governmental Organizations (NGOs) in Local Level: Become Pragmatic or an Accelerator of a Good Governance?
}

\author{
Edy Budi Susilo, Hary Yuswadi \\ Doctoral Program, Faculty of Social and Political Science University of Jember, \\ The lecturer of Social and Political Science faculty University of Jember
}

\begin{abstract}
This study focused on the interaction of non-governmental organizations (NGOs) and government bureaucracy. This type of study used qualitative descriptive studies, concluded that the interaction between $N G O s$ and government bureaucracy in Jember is still hard to actuate a good governance. It's caused NGOs still focus their orientation on interests of individuals or each groups, so that less favors the interests of the community. occurred because the typology of Government Bureaucracy was more dominant on conservative rather than visionary. On the other hand the typology of NGOs in Jember dominantly was also more pragmatic (NGOs were affiliated on businessmen, officials, political parties and economical interests) compared to NGOs that are idealistic. So that in doing the interaction, government bureaucracy and NGOs more dominant only oriented on pragmatic interests mere (individually, group) than to public interest. It occurred because the typology of NGOs were more dominantly on pragmatic orientation (NGOs are affiliated on businessmen, officials, political parties and economical interests) compared to NGOs that are idealistic. Secondly, government bureaucracy in Jember is more dominant bureaucrats who are conservative compared to bureaucrats who are visionary. It is not only dominantly on the amount of but also in the position of its bureaucrats that average be in leaders level, so it tends to create a bad governance.
\end{abstract}

Key word: Government Bureaucracy, NGOs, Interactions and Good Governance

Public participation on order of democratic government requires the existence of public engagement in the decision-making process which is increasingly important in the era of regional autonomy. The implementation of regional autonomy by law (UU) No. 32 of 2004 concerning to Regional Governments, have brought major changes in each segment of the organization of Local Governance. Within the implementation of regional autonomy, local governance identified irregularities and doing a lot of misperceptions about the regional autonomy. Therefore, the role of the community in being critically participating and contributing in Government must be organized well, one of them is by joining non-governmental organizations (NGOs), it is important to maximize the contribution of the community to encourage good governance process.

The establishment of many NGOs become the important point to get attention from the committee of government, because the existence of NGOs is expected to prop up the process of governance done by government bureaucracy as the committee of government, to run it well and proportionate. It is also in accordance with UU No 17 / 2007 about National Long-Term Development Programs Planning (Rencana Pembangunan Jangka Panjang Nasional/ RPJPN) about the importance of providing the role of civil society in democratic governance. But that must be noticed, that the NGO contribution to governance and the consolidation of democracy does not happen by itself, there must be an interaction with the other party for instance by government bureaucracy, so that what is done by NGOs was later able to contribute a more visible in governance.

The form of NGOs contribution which is customarily done in governance is to actively involved in the policy stages (formulations, implementations and policy evaluations). With the involvement of NGOs in policy stages is expected to become a strategic partner in governance. Especially in the era of decentralization like now, the authority given by the central government to local governments is very large and broad, it becomes an opportunity as well as a challenge for NGOs to be in partnership with local government to improve its service to community.

The Governments of Jember which have been carried out the regional autonomy since the beginning of decentralization enacted, is considered necessary by the writer to be noticed and review how important the relations is between the interaction of government bureaucracy with the NGOs in governance. Moreover, Jember has the unique characteristics named Pandalungan, which is culture of java and madurese mixed and also dominated by culture of moslem students "Santri" with political conditions, social that is dynamic, who indirectly encourage the establishment of NGOs in Jember, based on data released by National Unity Political 
and Community Resilience of Jember (Bakesbangpol and Linmas) indicating that there are at least 141 NGOs legally registered in 2010.

The condition seems, bares the excitement of society to engage in administering government, to control the way that was formerly difficult due to lack of space provided by the government. Based on the description above hence this article will talk about "The interaction between bureaucracy government and NGOs in Jember in implementing good governance".

\section{Pragmatism of non-governmental organizations (NGOs): Its challenges in Jember}

Fair role of local government broadly to run the process of decentralizing, indirectly also causes the establishment of NGO in local, NGOs expected to bring people aspirations and become an effective controlling machine in administering government, besides the formal institution, as The District Legislative Council (DPRD II). A huge expectation to NGOs role occurred due to lots of authority misuse done by government. Based on data released by Ministry of Currents Affairs (Kemendagri ), there are 318 Region Heads being entangled corruption ( Metro TV, in a footnote, february 142014 ).

Based on studies that have been carried out by previous author in Jember, it's caused by pile authority that belongs to the Government bureaucracy, and also on the other hand the supervision carried out by DPRD II is often not optimally. The condition is caused by government bureaucracy in Jember already fragmented into two groups, such as: Conservative Bureaucrats and Visionary bureaucrats. Conservative Bureaucrats are more dominant compared to visionary. It is not only dominantly on the amount of but also in the position of its bureaucrats that average be in leaders level. Followings are reviews of bureaucrats condition in Jember:

Tabel. 1

The Typology of Bureaucracy Government in Jember

\begin{tabular}{|c|c|c|}
\hline Number & Type & Criteria \\
\hline 1. & Conservative Bureaucrats & $\begin{array}{ll}\text { - } & \text { Stagnant in way of view (conservative) } \\
\text { - } & \text { The involvement of stakeholders regarded as a threat } \\
\text { - } & \text { A change regarded as a threat to itself and its institutions }\end{array}$ \\
\hline 2. & Visionary bureaucrats & $\begin{array}{l}\text { - Way of looking far ahead (visionary) } \\
\text { - } \quad \text { Other stakeholder involvement is considered an inevitability to } \\
\text { be openly accepted as a strategic partner } \\
\text { A change is regarded as an opportunity to continue to improve } \\
\text { performance }\end{array}$ \\
\hline
\end{tabular}

Source: the data compiled from the field observations (2012- 2013)

The condition of that government bureaucracy, seemed differently as mentioned by Aberbach (1981), he added that government bureaucracy in performance based only on facts and knowledge and well-organized and effective (including in the interactions with NGOs). However, in fact what was told by Aberbach it does not reflect the entire empirical facts in the field. Because the government bureaucracy oriented beside based on fact and knowledge also on personal assumptions and political leader's interests. This condition is a challenge for NGOs to push government bureaucracy to change towards more optimal. Moreover, in the current reform their rights as guaranteed by the constitution. Based on the data served by Bakesbangpol and Linmas of Jember, the existing NGOs in Jember divided into several fields of study:

Tabel. 2

Field of study of NGOs in Jember

\begin{tabular}{|c|l|c|}
\hline Number & \multicolumn{1}{|c|}{ Field of study } & Amount \\
\hline 1. & Socio-economic & 2 \\
\hline 2. & Education & 1 \\
\hline 3. & Agriculture & 5 \\
\hline 4. & Community empowerment & 2 \\
\hline 5. & Health & 30 \\
\hline 6. & Social & $\mathbf{4 2}$ \\
\hline
\end{tabular}

Source: Bakesbangpol dan Linmas Jember (2010)

Field of study of NGOs which is quite varied, as mentioned on Table.1, give a signal that Jember society are already proficient in the essential role of their involvement in governance. But the participation level of those NGOs apparently still has not been accompanied by an increase in human resources that is particularly important, the average education of NGOs committee is only junior and high school, and lack of people have education as scholar. Therefore they have not been able to show a significant contribution in governance. Based on the results of the study, many people set up NGOS only patterned its group and individual interests, for the purpose of earning money and beneficial project from their involvement in organizing a government. It accords 
with what delivered by Aberbach (1981), according to him, the NGOs in the its orientation can be based on the interests of individuals, groups and political sensitivity. In the context of this individual interests, more NGOs emphasize on each member's which are full of egocentric personal interests. Whereas regarding to groups interests, NGOs show the accumulation of interests of each individual. As for the political sensitivity, their concern is the sensitivity of NGOs against the public interest which is based on the vision, mission and objectives of the NGOs.

In fact, NGOs in Jember are oriented tending more to interests of individuals and groups than political sensitivity. In this case NGOs in their performance is based more on interests of individuals and groups than from the process of democratization and commitment to protect public interests and eventually it often reduced the political sensitivity so NGOs interests tend to be more pragmatic oriented than reveals the attitudes of idealist. Thus typology of Aberbach about NGOs helps to explain the phenomenon which seems the orientation of NGOs in Jember are more dominant turns on individual interests and lacking political sensitivity so inclined to overlook the public interest.

That condition happened because NGOs in Jember have been polarized in the interests of affiliates, namely the interests of officials, political parties, businessman, economic interests and the interests of the idealist. Following a full review of NGOs affiliation forms in Jember:

Tabel. 3

Typology of NGOs in Jember

\begin{tabular}{|c|c|c|c|}
\hline Number & Affiliated with & Category & Criteria \\
\hline 1. & Government bureaucracy & Pragmatic & $\begin{array}{l}\text { - Support bureaucrats, to depress the leaders } \\
\text { in order to increase the bargaining position } \\
\text { of the bureaucrats } \\
\text { - The aim is to gain advantage of money and } \\
\text { projects, as a compensation of their support }\end{array}$ \\
\hline 2. & Political parties & Pragmatic & $\begin{array}{l}\text { - Support political parties, to depress } \\
\text { Legislatives and Executives } \\
\text { That support is about pressure extra } \\
\text { parliamentary } \\
\text { - The aim is to earn money and power }\end{array}$ \\
\hline 3. & Businessmen & Pragmatic & $\begin{array}{l}\text { - } \quad \text { Support the businessmen in gaining projects } \\
\text { - } \quad \text { The aim is to earn money }\end{array}$ \\
\hline 4. & Money or project oriented & Pragmatic & $\begin{array}{l}\text { - NGO does not focus on a particular interest } \\
\text { group affiliations, but this could be } \\
\text { affiliated with any interest group, as long as } \\
\text { the group can meet the needs of the NGOs } \\
\text { (money and projects) } \\
\text { - Mode or the working system of this NGO is } \\
\text { the investigation and criticized the } \\
\text { Government's policies and programs with } \\
\text { the goal of money and projects }\end{array}$ \\
\hline 5. & Idealist NGO & Idealistic & $\begin{array}{l}\text { - Favors to public interests } \\
\text { - } \quad \text { Escort the administering government } \\
\text { system to create a good governance } \\
\text { - Community empowerment }\end{array}$ \\
\hline
\end{tabular}

Source: Data Adapted from Field Study Results (2012-2013)

To strengthen the opinions, the writer would take one example of cases which demonstrate the main role of NGOs as the pressure power in Jember i.e. ruislag of land case belongs to Headquarters of the Army Strategic Reserves Command of Jember (Brigif 9 Kostrad) in 2010, a NGO named Yayasan Abdi Masyarakat highlighted the alleged irregularities data in the ruislag procedure and then reported it to law enforcement agencies, it finally responded by Prosecutor of East Java (Kejaksaan Tinggi Jawa Timur) and faced it to the court.

The case was started from the willing of Brigif 9 Kostrad who wanted to move its headquarters on Jalan Gajah Mada to other area which is more representative, considering the condition of buildings unfeasible. Due to that need, communication and negotiations held between Military Area Command (Kodam V Brawijaya), Brigif 9 Kostrad and the Regent on behalf of the government of Jember.

Based on the agreement of ruislag between Brigif 9 Kostrad and Government of Jember, so Committee 9 was established to do further assessment of that agreement. This committee was chaired by the Secretary of District (Sekkab) with the Assistant of Deputy Chairman of Governmental Sector (Wakil Ketua Asisten Bidang Pemerintahan) and as a secretary is Chief of General Governance (Kabag Pemerintahan Umum). From the results of the assessment conducted by Committee 9, some important decisions made and one was related to pricing point, Committee 9 reported that assets value of Birigif 9 Kostrad was appraised about 9 billion based on 
the Selling Value of Tax Object (Nilai Jual Objek Pajak) in Kaliwates sub-district (Kelurahan Kaliwates) and the appraisal made by Committee 9. Considering to the recommendations of Committee 9, The Regent followed it up by publishing a Decree (SK) about the ruislag and hence the Regent reported it to District Legislative Council of Jember (DPRD) in order to permit that ruislag executed to the assets.

The process of ruislag attracted one of investors, namely PT. Pesona Surya Milenia to have an agreement on the ownership of that headquarters. The administrative process related ruislag soon be handled by, either through Jember Goverment as well as the Headquarters of the Indonesian National Army (MABES TNI AD) and KODAM V Brawijaya. After the administrative process was completed, and regent set the value of the land is worth about 9 billion rupiah. Next, regent allowed to release the assets on condition investors should pay 9 billion rupiah to local administration and investors should also develop facilities and infrastructures in the District Hospital of Jember named RSUD dr. Soebandi. After it was agreed upon by the investor, newly known it turned out that assets occupied by Brigif 9 Kostrad legally owned by Jember Government so that the ruislag process was voided. But negotiations between Jember Government and investors continued in changing the ruislag into sales in order to increase District Income (PAD).

Renegotiation between Jember Goverment and investor agreed that the discharge assets occupied by Brigif 9 Kostrad was through sales between government and investors, no longer as ruislag. Because there was also the building then regent asked the price increased from 9 billion to 11 billion rupiah, regent also asked investors willing to build new headquarters of Brigif 9 Kostrad in area named Kreongan and investor agreed with it. Due to the change of agreement into sales, then it should have asked an approval of DPRD related to discharge assets. Administrative procedure has been done by Jember Goverment, but legal products of approval from DPRD on discharge assets referred was still in the process. On the other hand the process of sales carried by investor was already occurred, investor has paid about 11 billion and built new headquarters of Brigif 9 Kostrad in Kreongan.

New problems came up when The State Audit Board (BPK) conducted a routine check to Jember Government, BPK found a fact that the discharge assets of Brigif 9 Kostrad has not received an approval from DPRD. In addition the discharge of the assets were not through auction process and pricing decision was not based on independent appraisal so that specified price was considered not appropriate because much cheaper below NJOP and the current market price. According to the calculations of BPK, net selling price of the assets worth about 20 billion rupiah. It also upheld by the committee of independent appraisal from Kodam V Brawijaya who resulted price that was equal to 20 billion rupiah.

The findings of BPK indicate the misuse and the abuse of authority done by Committee 9 , by conducting public falsehood based on differences of NJOP calculations between BPK and Committee 9. In the Committee 9 report mentioned only worth 9 billion rupiah. So, when the findings of BPK were known among NGOs, they immediately clarified it to Committee 9 referred to Secretary of District (SEKKAB) and the Assistant of Deputy Chairman of Governmental Sector and Chief of General Governance. But the act of clarification done by NGOs would not get a positive response from those three officials, instead of an excessive defense. Excessive defense was evidenced by one voice statement, that all related to the process of Government's assets occupied by Brigif 9 Kostrad was in accordance with a mechanism that should have been used. Even though they couldn't evasive if the process of appraisal made by the Committee 9 was in contrary to BPK's.

The deadlock communication and the settlement, allegedly because NGOs are often considered critical to government policy, on the other hand there is a political consideration, since it was considered that NGOs are the supporter of the former regent and unwell received by current leaders. So that clarification was not capable to respond well proportioned by officials. In fact an indication of clarification of NGOs to Committee 9 was allegedly only pragmatic (only money ), it was done by most of the NGOs in Jember. How to get into government bureaucracy, NGOs usually carry on negotiations by doing clarification, by the time, clarification is done usually shows their real interest which the writer's observed is mostly about money and projects. But if it is not served by government bureaucracy, they appear, critical attitude even rises to legal proceedings. It is justified by some NGOs that some suspected often "squeeze" officials. According to him, if an agreement and compromise achieved between NGOs and the Committee 9, he added, it was not going on law enforcement level that was Public Prosecutor of East Java (Kejaksaan Tinggi Jawa Timur).

One other case related to problems of administering government in Jember which was highlighted by NGOs and been reported to the law enforcement that is recently in process of investigation, even prosecution, for example: alleged corruption on project of Special Allocation Fund (DAK) which was worth about 20 billion rupiah. It conducted in District Education Board of Jember, even dragging some officials into. Due to that criminal act, the state harmed about 3 billion rupiah. Project that funded by DAK aimed to supply procurement books and properties of school in 2010.

The same case also afflicted some officials in The Health Department of Jember about the alleged misuse of procuring health instruments. This case dated from the project in 2006. Project was budgeted from 
DAK and companion budget from Region Cash In that was about 900 million rupiah, alleged misused by vendors involving Health Department Officials by marking up some price of properties. The losses to the state, are estimated 396 million rupiah and even until now it isn't accomplished yet by the vendors to fulfill that project (contract dated from July 26 to September 2006). Hence the issues reported by NGOs on law enforcement.

Examples of such cases showed that NGOs actually have a pressure power which is capable of being a power control for performance of government bureaucracy to make it more useful. However, on the other hand it also provides space on the pragmatic NGOs to take advantage (money and projects) and squeeze the Government bureaucracy involved in the case. This role is often seen in the interaction of NGOs and government bureaucracy in Jember.

\section{Conclusion}

Based on the descriptions above can be concluded that the interaction of non-governmental organizations (NGOs) in Jember is still hard to form and actuate a good governance. It's caused by NGOs still focus their orientation only on interests of an individual or each groups and so does bureaucracy government. Whereas NGOs' involvement in administering government is part of the mechanism of democracy in normative, allows transparency in terms of interactions between government bureaucracy and stakeholders. But in the context of practical often encourage the bad governance so it requires a policy that could build more constructive interactions.

That facts happened caused by: first, the existing NGOs in Jember are mostly more oriented to pragmatic interests (money and project) than NGOs who are idealist. Second, government bureaucracy in Jember is more dominant bureaucrats who are conservative compared with bureaucrats who are visionary.

\section{References}

[1]. Aberbach, Joel. D., et.al., 1981. Politicians and Bureaucrats in Western Democracy. London: Oxford University Press.

[2]. Bakesbangpol dan Linmas Jember (2012)

[3]. Metro TV, In footnote, February 14, 2014

[4]. Toha, Miftah. 2003. Dimensions of Public Administration. Jakarta: PT. Radja Grafindo Persada

[5]. Hagul, Peter. (1995). Rural Development and NGOs, Rajawali, Jakarta.

[6]. http://www.suaramandar.com

[7]. Law of the Republic of Indonesia Number 32 Year 2004 on Regional Government. 